\title{
Redefinition of the notion of Universal Access to the health care
}

\author{
Rubin Zareski \\ Faculty of Pharmacy, University Ss Cyril and Methodius, Mother Tereza 47, 1000 Skopje, Republic of Macedonia
}

Received: September 2014; Accepted: December 2014

\begin{abstract}
In the last 10 years we are experiencing hidden debate where decision makers do not want to opt for the "unpopular" decisions, which need to be taken if we need a sustainable health systems on a long run. Lessons from the 2008 crisis have proven that policy decisions driven by external global forces that are beyond our controlwere inconsistent and reasonable damaging also on a mid term run. Instead of addressing the core of the problem, in the attempt to reply to the old/new challenges, governments were "fanning the fire". It becomes obvious that spending more money in uncoordinated way will not solve the problem. Reducing the cost by cutting the fiscal budgets, would further "squeeze" the capacity of the economies and reduce the demand, which has to be driver to the solution and not the problem. Consequently in a high market developed economies, cutting the health budgets will only temporarily "make up" the state budgets, creating structural financial instability of the Funds both private and State. In this lose-lose situation, with existing misbalances, contracting budgets, increasing demand and sensitive market players responses, there is a high time for redefinition of the Universal access to the health care systems and global policy responses which will on long term create balanced and sustainable growth of health markets.
\end{abstract}

Keywords: pharmacoeconomics, drug costs, new common model, health technology assessment

\section{Introduction}

Continuous loss of competitiveness in the European Union (EU) countries caused primarily because of the declining productivity levels, resulted in a recession or stagnation of Gross Domestic Product (GDP) driven further by the low demand levels. Policy makers' responses to the structural problems of the economies were rather confusing. Most of them opted to cut the budgets and reduce the deficits,instead of implementing countercyclical policies of spending more money in order to increase the demand in the economies and protect households' budgets. The element of decision in the contracting economies is very simple, states must increase the spending'sas answer to the financial problems instead of creating a cost cutting measures. While doing so, Governments must introduce so called expenditure switching policies of the state budgets

\footnotetext{
*rubin@trust.com.mk
}

including the health transfers, and to do this in a very controlled way. This will result in the partial solution of the existing fiscal disbalances but most important, it will put the large state funds into function as main drivers to the economy. This new policies will on the mid term essentially result with the stimulating mechanisms of increasing demand in the economies, including the health segment.

The fact that prevention and primary care have been mostly affected areas with the cuts on average of $13 \%$ (WHO Policy paper report 12, 2014) leaves no room for optimism that the gap will be covered in the next 5-10 years. With average 3.3\% fall of the European GDP and the unemployment levels rising to $11 \%$, (The World Bank indicators 2015, http://data.worldbank.org/indicator/NY.GDP. PCAP.CD/countries/EU), fiscal pressure on the governments forced them to reallocate public resources and spending's. More than half of the EU countries have reduced the health budgets in the attempt to limit the costs and finance other areas. The feedback of this new policies 
was with limited effects, simply because in attempt to address the problems, Governments were not dealing with the reasons. They have only been trying to balance the results. However, health systems generally need more, not fewer, resources in an economic crisis and there is good evidence underlining the importance of countercyclical public spending, especially on social and health sectors.

Ensuring that levels of public funding for the health system are adequate, public revenue flows are then predictable and revenue will be raised in a way that does not unfairly burden households. These are essential elements to promoting financial protection, equitable access to effective health services and equity in financing. Making this system sustainable requires that the Governments implement change to the way health care is funded and delivered, which limits the services provided by the state - creating new losers as well as winners. Although Governments may be pleased by this changed position, on the long run they will face with more problems than ever. Reason is simple:external global forces often beyond the control of individual states are driving the crisis. Governments don't want to opt for less control of the processes and to give up part of their economic sovereignty. In this new environment, pharmaceutical companies may experience price pressure, at the same time benefiting from the major shift in the policy implementation by trading price for access to markets.

\section{Rationing of the New Model/some numbers}

Recently published paper on the European policy framework and strategy for the $21^{\text {st }}$ century called "Health 2020 ", surprisingly just confirms the old policies of invest- ing in health through a life-course approach and by empowering people. In fact there is no change in the policies where the same ideas remain in the core of the health policies in the developed world for the last 30 years. Seems that there is no flexibility in the redefinition of some of the elements of the global systems that need to take the existing challenges to a whole new level. However, today more than ever before there is political willingness to address waste in the health systems and to possible reduce input costs without undermining performance and the gap between revenue and expenditures. The major challenge is how to transfer the rise of the expenditures and burden the taxpayers and ask them to pay more money when it does not make sense because of their budgetary limits. This is when the so-calledpolicy of efficiency gains will take place. This process might be painful but the facts of how the health problems have been addressed and results produced cannot be satisfactory. Something will need to change.

Lets address the facts. The demographic transformation in the countries requires an effective life-course strategy that gives priority to new approaches for promoting health and preventing disease. Healthy and active ageing is a policy priority and a major research priority. On the other side scarcity of resources is further deepening the gap between the developed countries and the remaining world. This leaves us with the question of why global health systems are unsustainable and have to change? Healthcare in 2013 consumes $12 \%$ of global GDP, and is estimated a $\$ 5.3$ trillion industry (WHO annual report, 2014). The dynamics of the process shows that spending's is growing at average of $3 \%$ per annum, which will double the expenditure in less than 20 years. By 2080, 50\% of world GDP will be spend on health costs (McKinzey\&Company Quarter-

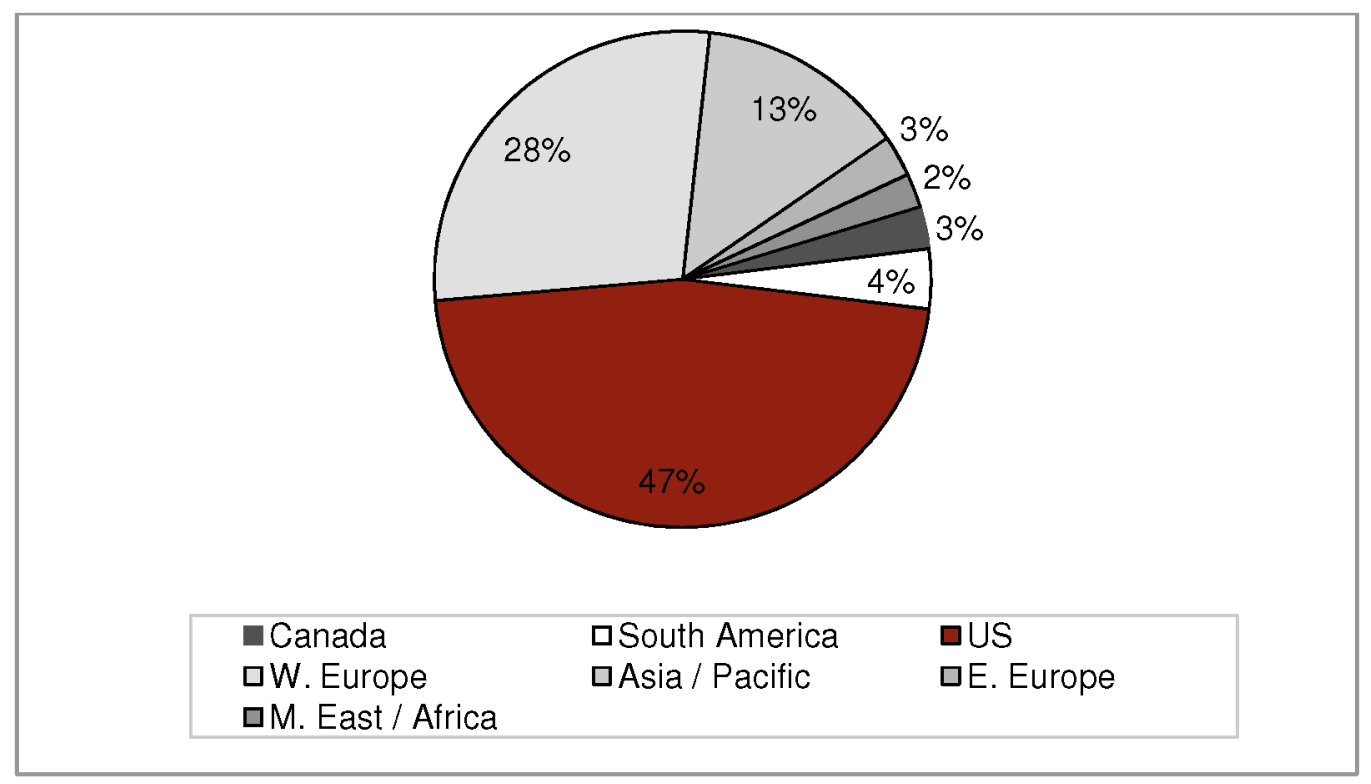

Fig. 1. Global health spending. 
ly, 2008). This is not a surprise if we know that in the last 15 years health expenditures in the OECD countries have doubled, reaching average 13\% share of the GDP (OECD, WHO annual reports 2014- Growth rate, average growth in spending in OECD countries 1995-2015). Inevitably fundamental global forces will change the way systems work. Finding a right balance between global trends, emergence of a new Common Model and implications need to be positioned in the focus of all debates. Results will answer to the following questions: (i) What is driving the evolution of health care globally? (ii) How are health systems reacting to this? (iii) What does this mean for Governments \& the Pharma industry?

Existing disbalances in the world health care markets cannot be sustainable in the next period of 20 years. Numbers show that the consumption of the health expenditures is dominated by the USA, which with $5 \%$ of world population spends over $45 \%$ of total healthcare (Espicom, Industry report 2014). Furthermore, top 20 countries account for $90 \%$ of spend, which leaves to $84 \%$ of world population shares $11 \%$ of spending, but suffers $95 \%$ of diseases (Fig. 1).

What becomes evident from the numbers is that population growth and wealth trends will in the future drive healthcare demand towards the developing countries (Fig. 2).

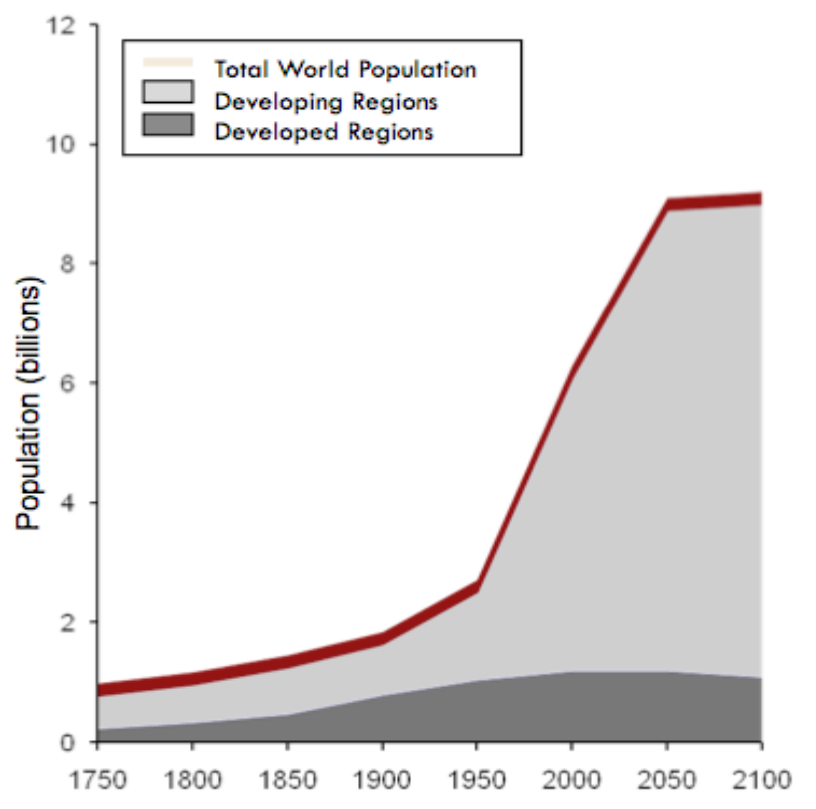

Source: Population Reference Bureau, U.S. Census Bureau 2014

Fig. 2. Population trends 1750-2100.

Growth in importance of developing/emerging markets will produce inequality to be unjustifiable, challenging the decision makers to meet basic health needs, of a growing "middle class" with developed world diseases, expectations, and money. This will produce need for redefinition of the global health policies, whereby balanced sus- tainable good health practices throughout the life-course will lead towards increasing healthy life expectancy. Result will produce important economic, societal and individual benefits. Strong evidence indicates that these costeffective policy pathways can directly enhance population health and well-being. Creating better conditions for health, improving health literacy and making the healthier choice the easier choice, remains the driving factor, while attempting to address this burning problem of the increasing health expenditures in the developing countries. With population shifting to developing world and increasing wealth demands, health expenditure will rooftop creating continuous pressure to Governments to act (Fig. 3). Major reforms will reduce the reliance on market forces in which uncontrolled costs and unpropotioned relative performance is not sustainable. Both elements of the realignment to demographic shift and balancing of funding and expenditure will mark the future health policies.

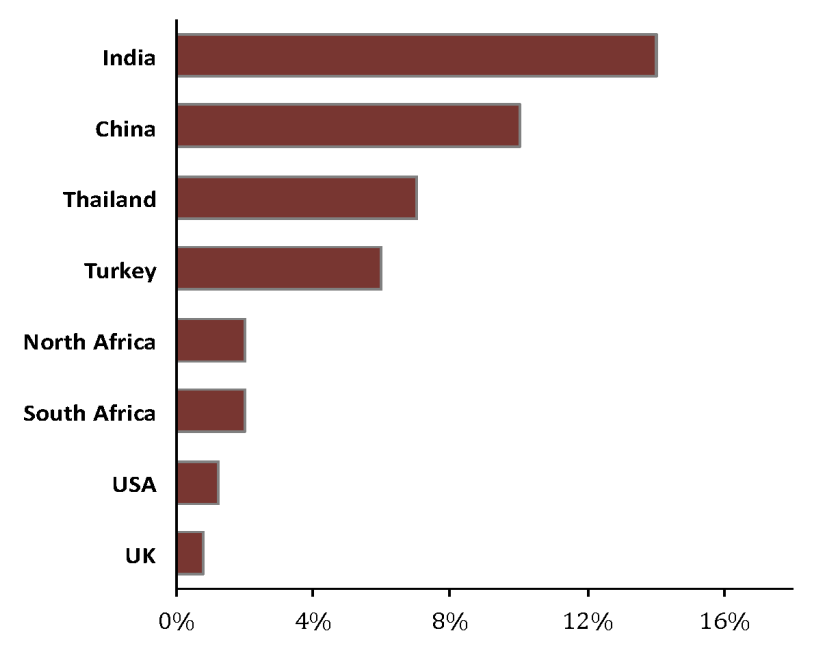

Source: World Bank, U.S. Census Bureau 2014

Fig. 3. Compound Annual Growth Rate Consumer earning $>\$ 10 \mathrm{~K}$ Purchasing Power Parity.

\section{Universal access to the health care}

While in Europe, most Governments are not yet ready to admit the "social contract" is under challenge, rationing of universal provision is inevitable. Universal access to the healthcare as a human right with the basic premises of equality of health outcomes, consumer choice and patient safetyis no longer affordable. Reason for this relies on the necessity to address widening inequalities in parallel to the pressures to increase healthcare spending and the new diseases caused by lifestyle and "medicalisation" as well as the new technologies to keep people alive and active. Finally, the pressure to increase the costs is coming from the increasing number of economically inactive people with high health needs. This is conflicting the possibili- 
ty frontier and putting limit to the public funding of healthcare, based on the belief in "small" government and limits to taxation.

One of the major characteristics of the healthcare systems in the last 10 years is that they have moved progressively towards increased rationing, as other interventions have failed. Combining government leadership, supportive environments and approaches that promote a sense of control and empowerment can lead to success only after certain level of strengthening of social behavioral research is provided as growing evidence to underpin such developments. Health promotion programs based on principles of engagement and empowerment offer real benefits. However, options are limited to the implementation of the changes to improve efficiency, but control demand. While patient co-payment can be expected to rise, there is no political decision/agreement on how much the patient can bear. Governments need to shift spending to where it can deliver greatest health gain, but it's not just a rational decision. To achieve this goal both cost saving potentials and Quality of adjusted life years (QUALY)analysis has to be done throughout the major health lifecycle. Inevitably Governments should focus on spending's/investments that have the biggest impact on the health of the nation. In doing so, rationing of the services with implementation of clear mechanisms must take a lead to the health spending's. Governments should focus on the easiest and least contentious first, postponing the decisions for improving of the reference-pricing list, which is not an easy task. In par- allel this balancing policy has to limit the scope of "Core Services" paid through taxation, releasing the budget pressure. Decisions are partly rational, but also driven by societal preferences, political readiness and partisan pressure.

The most difficult issue will be the content of "core provision" - and this choice is arbitrary. There is no known piece of work that tells you what the threshold for Health technology assessment (HTA) should be, and yet, something has to be done. Broad scope of participants, stakeholders, requires not one, but series of consecutive actions to bridge the existing gap between needs and capacities. Developed markets will need to decrease the affordability gap as defined by the HTA by squeezing the expenditures for the services that are not cost effective. In doing so, priority conditions have to be in the focus of the actions. As example, they should only in limited way address the local epidemiology problems. While doing so this group of countries has to give a high attention to the services which reduce overall burden on the health system and country, such as mental health, rehabilitation, prevention, screening, education, generics. Finally, developed countries must keep the main focus of financing and policy structuring to the services considered to be essential for basic health needs. Among others primarily to the care of the elderly, sanitation, nutrition, control of infectious diseases, accident \& emergency care. (Fig. 4)

In parallel to these priority elements in the developed countries, developing markets will be forced to increase budgets allocated to health and to move from covering of

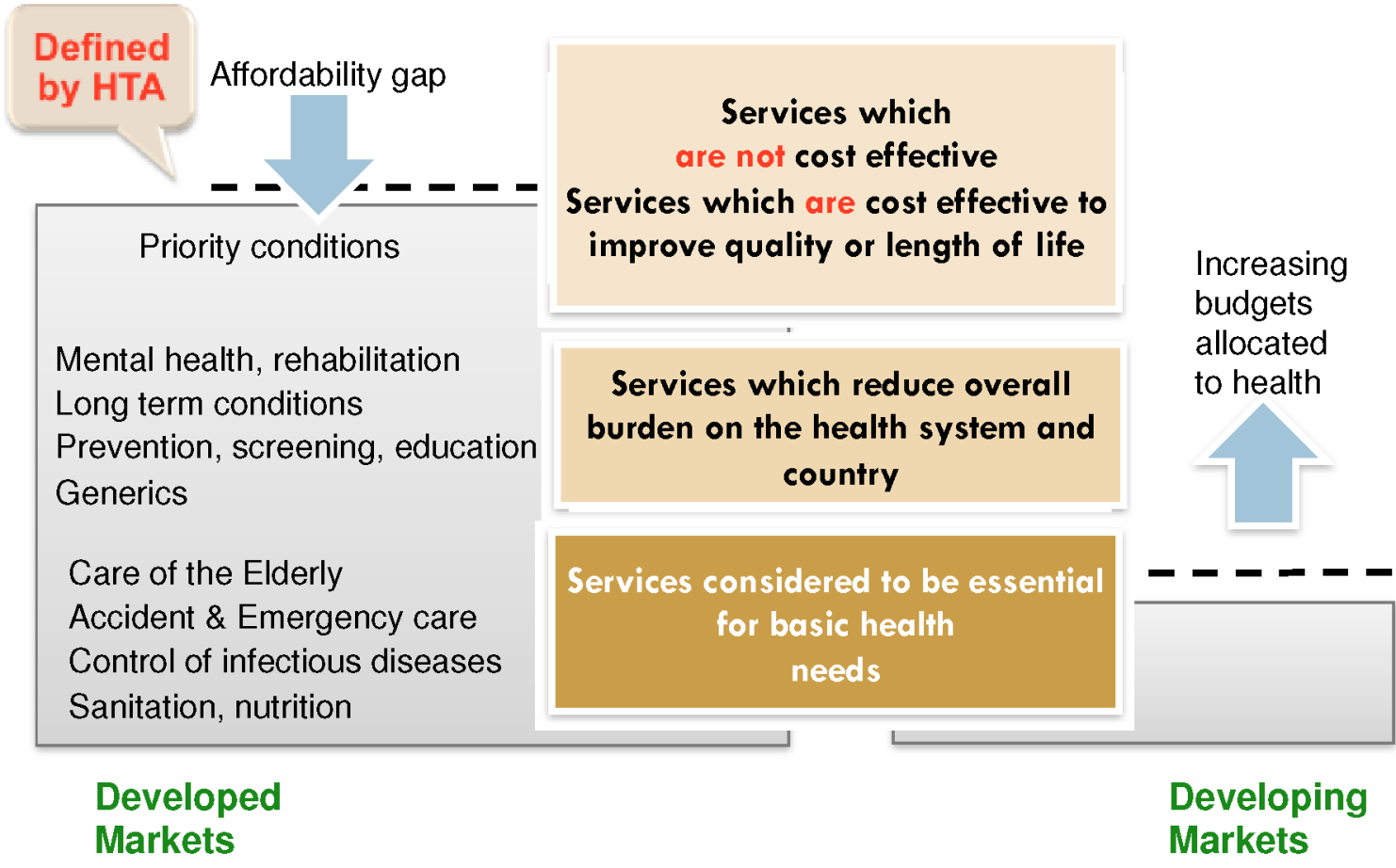

Fig. 4. Approach to the new health rationing. 
the essential needs, towards prevention services and education, process which is opposite to the one in the developed countries. Balancing of those 2 approaches will result in balancing of the spending's, priorities and health markets. Eventually all health systems will converge largely into the same system structure.

\section{One way street}

Government can proceed to the new Common model by design, or by default. This course of actions cannot be reversed due to the fact that health market conditions have been changed and time is valuable category. In their intention to control the processes Governments will have to implement a list of measures and policy decisions that will in the core of the substance involve use of pharmacoeconomics so that they will avoid any voluntary and subjective choice. Reason for this is even stronger considering the "narrowband" pharmaceutical producers are experiencing in the last 10 years. Finally, transparent but also favorable policy for all interested groups (producers, health workers, patients) must be packed into sustainable Model which on a long term will produce win-win situation for all involved participants.

Definition of the new Model requires list of actions all partners in the Deal will perform (Fig. 5). The role of the Governments will remain more or less without changes but with higher focus on the core service elements. Pri- oritization of the Governments actions will be given to the emergency care, public health, prevention, mental health, disadvantaged groups which will be financed by taxation or compulsory contributions. On the other side payers will face with managed distribution of the "core service" funds and have market freedoms for non-core funding. Providers of the services and products that are represented by mix of public and private operators in this new Model will focus more on the regional planning activities which will also address the disbalances in the developments and presence. While doing so, they will be financed by tariff based payments but will also have to experience increasing use of capitated/risk share. Fourth partner in this New deal/Model are suppliers which will continue to face with regulated prices and pressures to cut the cost and increase the effectiveness. Moreover suppliers will need to further adapt to the rules of centralised procurement with strict evaluation of cost effectiveness ratios. Naturally, they will benefit from the new growing markets and economies of scales. Finally, in the core of the Model are citizens, segment that will need to accept a more controlled process. Tax or compulsory contributions will not change as core elements for financing of the health needs. The new role will be mostly in the areas of limited co-payments where citizens will experience control of demand keeping gate for expensive acute care services. Of course self-payment/insurance will remain for the non-core services.

The process that according to many signals has already started but needs to be with higher level of determination

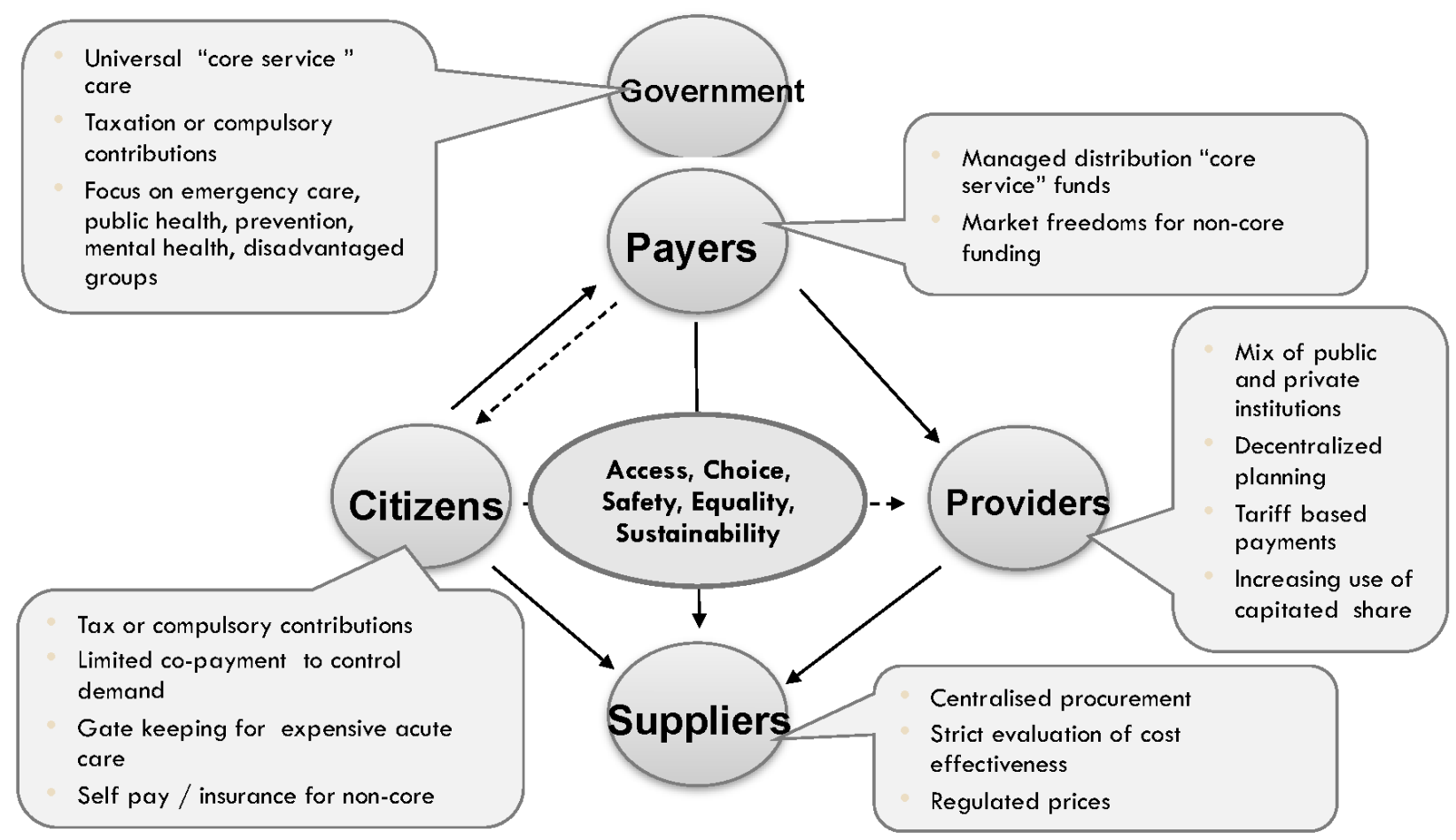

Fig. 5. New Common Model. 
by the actors, is positioning the Government in the driver seat. It is therefore of no surprise that reaction to these new developments can be increase of the monopsony behaviour. This is the price that needs to be paid as counterweight to the economic and rational actions they will have to perform. Among others, Government will have to increase the budgets and switch the expenditures with higher focus towards preventive and primary care, to involve pharmacoeconomic studies in the assessments and address the demands from the innovative drug companies.

\section{Conclusions}

Increasing costs, stagnating demand, existing disbalances and prevention of the households and state budgets, by default create a need for introduction of a new common Model for financing of health care. The core of this Model is the redefinition of the notion of universal access to the health care, service prioritization and budget reallocations. Decisions will require more profound use of pharmacoeconomic studies that will focus on what really drives treatment decisions and what new data would be viewed as clinically meaningful for prescribers and value-creating for economic stakeholders. This requires series of actions on a global world level, which must not be exhaustive ones or limited, but rather a coordinated list of performances on a global scale basis. Process which will address all actors in the field of policy definitions and practice will start by initiation of a detailed analysis, including assessment of the critical drivers of behavior for each stakeholder (prescriber, payer, and patient behavior). The substance of this action is to deliver the global targets by inclusion and not exclusion of the major stakeholders. In this way they will be assertive but also creative elements of the process. Therefore stakeholder perception and its reflection in understanding of how competitors are perceived by each stakeholder against the most critical factors (financing, sustainability, covering, scope of services, budgets, tax policies etc.), which can help identify unmet needs, it is of utmost importance. This may request further detailed comparison of competitor labels and clinical data to informthe decision makers which efficacy and safety endpoints matter most. Branded results of this action point will then be mapped against the competitor label and clinical data so to enable more granular understanding of real-world data on treatment decisions and outcomes.

Final outcome of this process that will consume some years before it is fully addressed and results are evident, will be a balancing act between the producers, services providers, decision makers, payers and consumers. All parties involved will therefore experience a full package of actions based on a clear pharmacoeconomic studies and HTA reports. The sooner this process starts with full dynamics the faster results will come, preventing the negative developments we have experienced in the last 10 years.

\section{References}

Brown, M., Nemetz A., Morley A., Bosanquet, N., Taylor, J., Fluck, R., Brambleby, P., 2013. Integrated care, Acollection of essays. pp. 11-31.

Chevalier, F., Levitan, J., 2009. Hospitals in the EU.Collection Europa Dexia. pp. 34-36, 85-97.

Drouin, P.J., Hediger, V., Henke, N., 2008. Health care costs: A market-based view, The McKinseyQuarterly.

Espicom., 2014. Industry report 2014

Funtleyder, L., 2009. Healthcare investing. McGraw-Hill Finance \& Investing, pp. 188-235.

McKinsey\&Company.,2010. Invention reinvented, Pharma R\&D Compendium.

Organization for Economic Cooperation and Development, WHO, https://data.oecd.org/health.htm Growth rate average growth in spending in OECD countries 1995-2014.

Pikkety, T., 1971. Capital of the 21 century, translated 2014 for Harvard University Press, pp. 170-192.

Thomson, S., Figueras, J., Evetovits, T., Jowett, M., Mladovsky, P., Maresso, A., Cylus, J., Karanikolos, M., Kluge, H., 2014. Economic crisis, health systems and health in Europe: impact and implications for policy, WHO Policy summary 12 .

Thomson, S., Foubister, T., Mossialos, E., 2009. Financing health care in the European Union- Challenges and policy responses, WHO 2009, on behalf of the European Observatory on Health Systems and Policies.

UK Pharmaceutical Industry Competitiveness Task Force., 2012. http://webarchive.nationalarchives.gov.uk/+/www.dh.gov. $\mathrm{uk} / \mathrm{ab} /$ Archive/PICTF/index.htm

World Health Organization, 2014. Annual report.

Zareski, R., 2011. Basics of Pharmacoeconomics, Akademika, pp. 36-57. 


\title{
Резиме
}

\section{Редефинирање на значењето на Универзален пристап кон здравствените услуги}

\author{
Рубин Зарески \\ Фармацевйски факулиетеи, Универзииеет̄ „Св. Кирил и Мейояиј“, Мајка Тереза 47, 1000 Скойје, \\ Рейубика Макеоонија
}

Клучни зборови: фармакоекономија, трошоци на лекови, нов заеднички модел, проценка на здравствените технологии

Во последните 10 години се случува скриена дебата во која носителите на одлуки не сакаат да се определат за „непопуларни“ одлуки, кои што треба да се донесат доколку ни треба долгорочен и одржлив здравствен систем. Лекциите од кризата во 2008 година докажаа дека политичките одлуки управувани од страна на развиените држави беа недоследни и исто така штетни до одреден степен на среден рок. Наместо да се зафатат со решавање на суштината на проблемот, во обидот да се одговори на старо-новите предизвици, владите делуваа ациклично и дополнително го усложнија проблемот. Станува очигледно дека трошењето пари на некоординиран начин нема да го реши проблемот. Намалувањето на трошоците преку кратење на фискалните буџети уште повеќе ќе ја зголеми неликвидноста на економиите и ќе ја намали побарувачката, што во суштина треба да води кон решение, а не да креира дополнителни проблеми. Како резултат на овие мерки, кратењето на здравствените буџети кај високоразвиените пазарни економии само привремено ќе ги „нашминка“ државните буџети, создавајќи структурна финансиска нестабилност и на приватните и на државните фондови. Во ваква ситуација во која секој губи, со постоечки дисбаланси, договорни буџети, зголемена побарувачка и барања на значајните пазарни играчи, крајно време е да се редефинира универзалниот пристап кон здравствените услуги и да се дефинираат глобалните политички ставови кои ќе создадат долгорочен избалансиран и одржлив раст на здравствените пазари. 
